\title{
Forskningsetikk på dagsordenen - debattene bak de etiske komiteene
}

\begin{abstract}
BAKGRUNN I denne artikkelen ser vi på to faktorer som bidro til å utløse og drive debatten om forskningsetiske komiteer (nå REK) i Norge i 1970-årene fremover: Revisjonen av Helsinkideklarasjonen ved en skandinavisk arbeidsgruppe og opprullingen av den såkalte Grosaken i norske riksdekkende medier.
\end{abstract}

KUNNSKAPSGRUNNLAG Vi har brukt eksisterende litteratur i form av bøker og artikler om forskningsetikkens historie hentet fra Universitetsbiblioteket ved Universitetet i Oslo og Nasjonalbiblioteket, databasen History of Science, Technology and Medicine og Retriever. Vi har gått gjennom utgaver av Dagbladet fra 1974 og aktuelle årganger av Tidsskrift for Den norske legeforening fra 1960- og 70-årene manuelt. Endelig har vi brukt arkiver ved Universitets- og høgskolerådet og Samfunnsvitenskapelig fakultet ved Universitetet i Oslo.

RESULTATER World Medical Associations 1975-revisjon av Helsinkideklarasjonen forutsatte bruk av uavhengige etiske komiteer for vurdering og veiledning av forskningsprosjekter. Gro-saken, som omhandlet uprøvning av atferdsterapeutisk behandling av en ung jente bosatt på institusjon, og den offentlige debatten rundt saken, førte med seg et krav fra offentligheten om tydeligere kontroll med og etisk regulering av forskningsvirksomhet.

FORTOLKNING Begge de to nevnte hendelsene ble aktivt brukt i argumentasjon for og i forarbeidet til at etiske komiteer for forskning ble opprettet.

Regionale forskningsetiske komiteer finnes i dag i alle landets helseregioner. Deres virksomhet er basert på flere lover, inkludert helseforskningsloven, personopplysningsloven og pasientrettighetsloven (1), i tillegg til internasjonale retningslinjer for helsefaglig forskning, som Helsinkideklarasjonen (2).

Komiteene forhåndsgodkjenner prosjekter som involverer forskning på mennesker og på humant biologisk materiale eller på helseopplysninger innsamlet gjennom klinisk praksis eller forskning (3). I sitt arbeid vurderer komiteene risikoen forsøkspersonene blir utsatt for, hvorvidt krav til informasjon og samtykke er møtt og hvorvidt den vitenskapelige kvaliteten og nytten rettferdiggjør forskningens inngripen i forsøkspersonenes liv (4).

De første norske forskningsetiske komiteene ble opprettet i 1985. Prosessen med utformingen av komiteene og det tidlige arbeidet disse gjorde, er beskrevet tidligere (5). Denne prosessen springer imidlertid ut av hendelser som ligger lenger tilbake i tid. $\mathrm{Vi}$ vil i denne artikkelen ta for oss to slike hendelser og vise hvilken rolle disse har spilt for den senere opprettelsen av komiteene: revisjonen av Helsinkideklarasjonen i 1975, med en tydelig oppfordring om bruk av etiske komiteer, og opprullingen av Grosaken i mediene i 1974, som tvang forskningsetikken frem i den offentlige debatten.

\section{Kunnskapsgrunnlag}

I arbeidet med denne artikkelen har vi søkt å få oversikt over eksisterende litteratur i form av bøker og artikler om forskningsetikkens historie i Universitetsbiblioteket ved Universitetet i Oslo og Nasjonalbiblioteket, i databasen History of Science, Technology and Medicine og i gamle aviser ved å søke i Retriever. Vi har også manuelt gjennomgått utgaver av Dagbladet fra 1974 og aktuelle årganger av Tidsskrift for Den norske legeforening.

Endelig har vi fått hjelp av Universitetsog høgskolerådet og Samfunnsvitenskapelig fakultet ved Universitetet i Oslo til å lete frem materiale i deres arkiver.

\section{Forskningsetikk i kjølvannet av den annen verdenskrig}

Medisinsk forskningsetikk ble tvunget frem i lyset etter at den såkalte legeprosessen i Nürnberg i 1947 avdekket omfattende medisinsk eksperimentering med innsatte i konsentrasjonsleirene under den annen verdenskrig. Forsøkene ble betraktet som åpenbart etisk uforsvarlige, både på grunn av deres natur og fordi de ble utført under tvang, direkte eller indirekte.

Blant rettssakens konsekvenser var den såkalte Nürnberg-kodeksen, et vedlegg til dommen, som skulle være en etisk veiledning for medisinsk forskning på mennesker $(6,7)$. Sentralt i kodeksen sto informert samtykke. Den slo fast at man ikke skulle utføre eksperimenter på personer som ikke kunne eller ville gi sitt frie, informerte samtykke - uansett grunn.

World Medical Association vedtok i 1964 den såkalte Helsinkideklarasjonen, som spe-

\section{Nadia Shad Paulsen}

nadia.paulsen@gmail.com

Det medisinske fakultet

Universitetet i Oslo

Anne Kveim Lie

Institutt for helse og samfunn

Universitetet i Oslo

Artikkelen er basert på en studentoppgave ved Det medisinske fakultet ved Universitetet i Oslo.

Engelsk oversettelse på www.tidsskriftet.no

\section{HOVEDBUDSKAP}

Helsinkideklarasjonen ble revidert i 1975. Revisjonen forutsatte bruk av uavhengige etiske komiteer for vurdering og veiledning av forskningsprosjekter

Den såkalte Gro-saken, som først ble omtalt i norske medier i 1974, dannet grunnlaget for en offentlig debatt omkring forskningsetiske reguleringer

Begge de to nevnte hendelsene ble aktivt brukt i argumentasjon for og i forarbeidet til opprettelsen av etiske komiteer for forskning, som var på plass fra 1985 

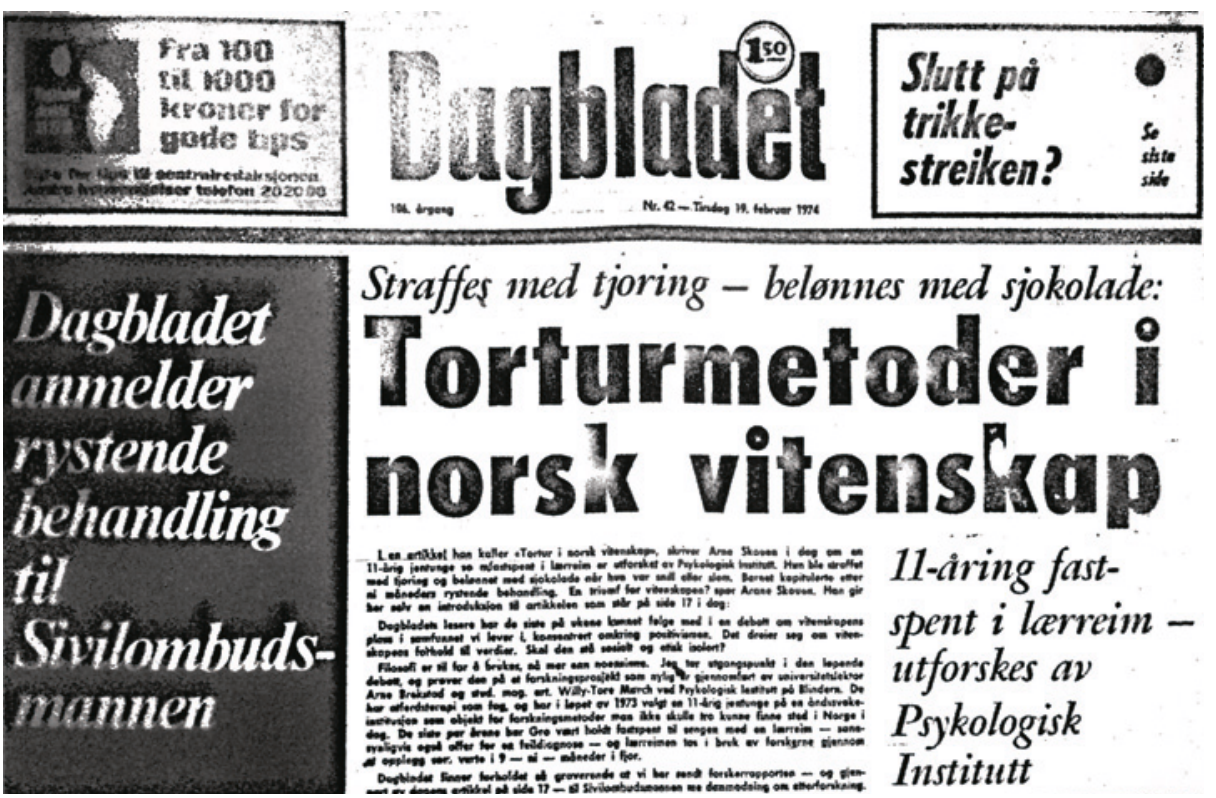

Straffes med tjoring - belønnes med sjokolade: Torfurmefoder i
nors

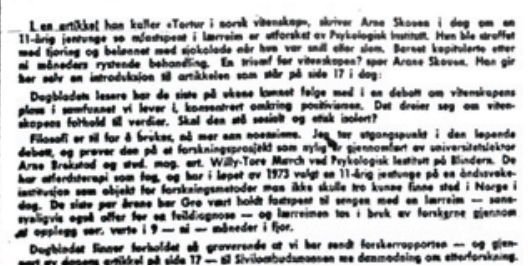

11-aring fast-

spent $i$ larreim -

utforskes av

Psykologisk

Institutt

Figur 1 Dagbladets forside 19. februar 1974

sifikt omhandlet etiske retningslinjer for medisinsk forskning. Det anses som allment akseptert at Nürnberg-kodeksen tjente som utgangspunkt for arbeidet med deklarasjonen (8). Det var imidlertid gjort noen vesentlige endringer fra Nürnberg-kodeksen. Deklarasjonen var skrevet av leger som skulle regulere egen virksomhet, ikke av en uavhengig rettsinstans, og legene hadde et annet syn på forskningsetikk enn dommerne i Nürnberg.

Deklarasjonen besto av generelle etiske retningslinjer for forskning, inndelt i klinisk terapeutisk forskning og ikke-terapeutisk forskning. Informert samtykke sto sentralt også i Helsinkideklarasjonen. Sistnevnte ga imidlertid, til forskjell fra Nürnberg-kodeksen, mulighet til å innhente samtykke fra forsøkspersonens verge ved klinisk terapeutisk forskning dersom vedkommende selv ikke kunne samtykke. Man hadde altså en mulighet til å omgå prinsippet om informert samtykke hvis man vurderte at forsøkspersonen ikke var kompetent, enten mentalt eller fysisk, og at den antatte nytten av eksperimentell terapi var stor. Ved ikketerapeutisk forskning var kravet derimot at personen var mentalt, fysisk og juridisk i stand til å fatte en egen, uavhengig beslutning (9).

Helsinkideklarasjonen ble enstemmig vedtatt av World Medical Association i 1964 etter et tiår med diskusjon og flere revisjoner underveis (8).

Få år etter Helsinkideklarasjonen kom det rapporter om uetisk forskning i både USA og Storbritannia. Den anerkjente amerikanske legen og forskeren Henry Beecher publiserte en artikkel i New England Journal of Medicine i 1966 (10), og briten Mau- rice Pappworth utga sin bok året etter (11). Begge omtalte samtidige tilfeller av uetisk forskning.

Beecher fastslo at «nesten alle er enige om at etiske overtramp finner sted. Det praktiske spørsmålet er, hvor ofte?». Begge forfatterne kommenterte at det i et fåtall av forskningsartiklene ble diskutert hvorvidt informert samtykke var innhentet. Beecher problematiserte konseptet «informert samtykke» og mente det var vanskelig praktisk gjennomførbart, men fastholdt at det likevel var et mål man alltid skal strebe mot av sosiologiske, etiske og juridiske grunner: «There is no choice in the matter» $(10$, s. 1355). Pappworth argumenterte i tillegg for forskningsetiske komiteer ved sykehusene.

Begge disse tekstene dannet grunnlag for en bred diskusjon blant forfatternes kolleger. Mange inntok en defensiv posisjon og påsto at de to forfatterne tok feil, at slikt ikke fant sted, og at denne kritikken uansett ikke skulle føres åpent (12). Legeprofesjonen ville helst ikke lufte skittentøyet sitt offentlig.

Likevel foregikk det en gradvis institusjonalisering av forskningsetikken i flere vestlige land i denne perioden. I USA hadde man hatt etisk fagfellevurdering fra begynnelsen av 1950-årene, og fra 1966 ble det et krav at alle forskningsprosjekter som innebar forskning på mennesker skulle forelegges en etisk komité $(13,14)$. For å motta støtte fra U.S. Public Health Service måtte prosjektene gjennomgå en ekstern vurdering av forskerens etiske dømmekraft før forskningsprosjektene kunne igangsettes. Vurderingen skulle bedømme forsøkspersonenes rettigheter og metodene som ble brukt for å innhente informert samtykke, og inneholde en avveining av risiko og mulig gevinst ved prosjektet (13).

Ettersom flere britiske forskningsmiljøer også mottok støtte fra Public Health Service, ble dette pålegget, sammen med diskusjonen Pappworth hadde startet, en viktig pådriver for at det også i Storbritannia ble opprettet faste forskningsetiske komiteer i 1972 (13). Sverige hadde hatt institusjonelle forskningsetiske komiteer siden 1966 (5).

I Norge ble det nødvendig å opprette ad hoc-komiteer fordi enten oppdragsgiver eller publisering i internasjonale tidsskrifter krevde det (15). På tross av den faglige debatten og institusjonaliseringen av forskningsetikken som foregikk i andre land, syntes det å være lite hastverk med å opprette faste komiteer. Her hjemme ble ytterligere to faktorer avgjørende: En anbefaling om uavhengige forskningskomiteer $i$ alle land i den reviderte Helsinkideklarasjonen, og eksternt press i form av den såkalte Grosaken.

\section{Revisjon av Helsinkideklarasjonen}

Tiårene etter den annen verdenskrig ga en stor vekst i forskningsmengden (16-21). Den medisinske kunnskapsbasen økte enormt, noe som førte til bedre og mer effektiv diagnostikk og behandling, både medikamentell og kirurgisk. Man så en eksplosjon i nye behandlingsmetoder, med antibiotika, antihypertensiver, antipsykotiske midler og transplantasjonskirurgi.

Medisinsk behandling ble en kommersiell gullgruve, og legemiddelindustrien fikk enorm vekst (21). Kravene til dokumentasjon av effekt og trygghet ved nye behandlingsmetoder økte tilsvarende. Samtidig møtte man nye utfordringer. Peter F. Hjort sammenfattet det i 1967 på denne måten: «I begynnelsen av århundret var det unge mennesker som døde, og de døde av tuberkulose og andre infeksjoner; i dag er det gamle mennesker som dør, og de dør av hjerte- og karsykdommer og kreft» (18 s. 1664).

Dette var noe av bakgrunnen for at World Medical Association besluttet å revidere Helsinkideklarasjonen i 1975 - omtrent ti år etter at den opprinnelig ble vedtatt. En skandinavisk arbeidsgruppe fikk i oppdrag fra sine respektive legeforeninger å jobbe frem en revisjon. Gruppen besto av danske Povl Riis (f. 1925), svenske Clarence Blomqvist (1925-1979) og norske Erik Enger (19272016) (22, 23).

Riis skrev i ettertid at det i Norden var lite kjennskap til den originale deklarasjonen og at den derfor var lite brukt (22, 24). Den gradvise overgangen fra små terapeutiske forsøk til en ny gullstandard for 


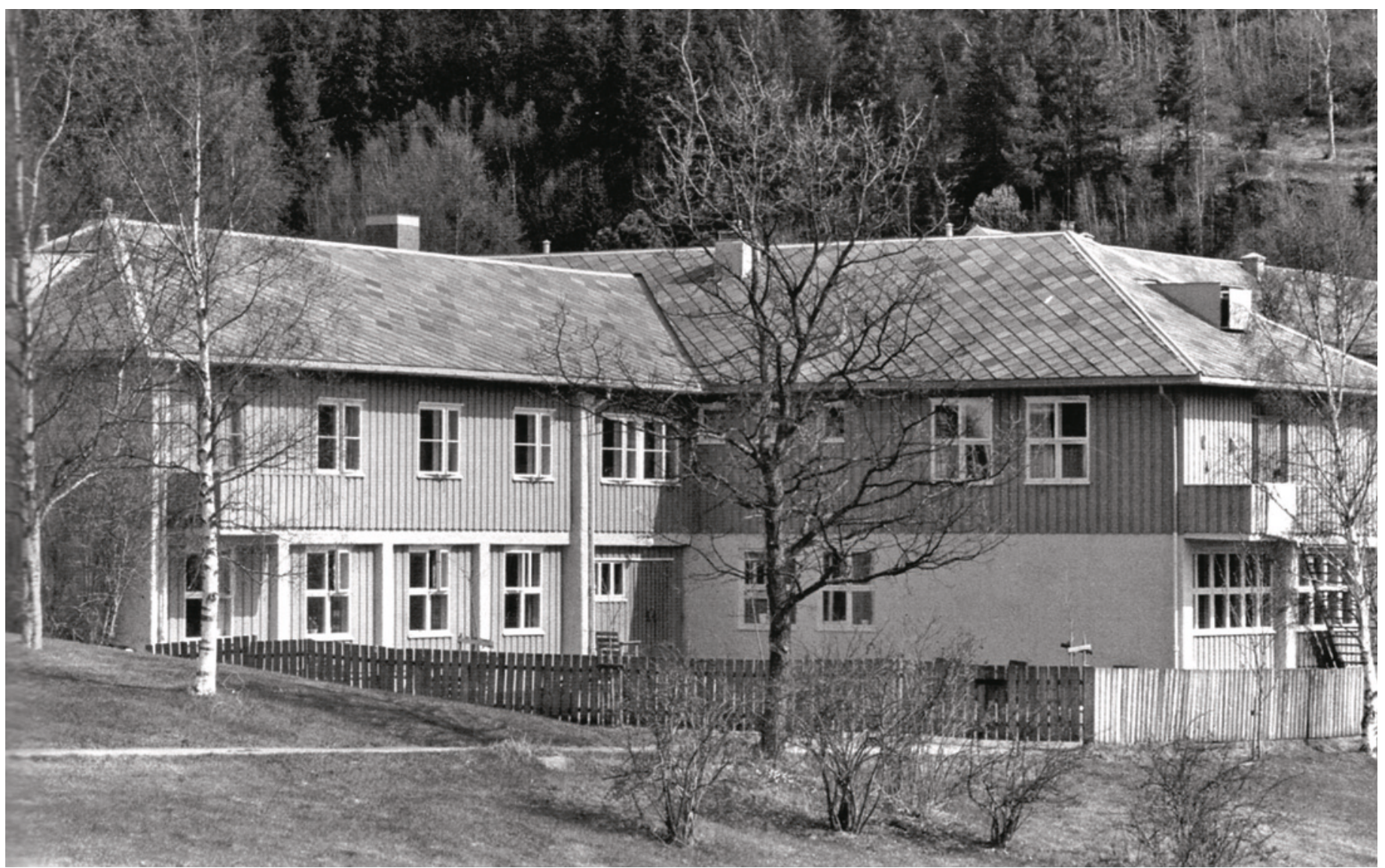

Figur 2 Solbakken ved Klæbu pleiehjem, institusjonen der Gro bodde. Foto: Ingar Johansen, Adresseavisen, 1983. Gjengitt med tillatelse fra Klæbu historielag (33)

medisinsk forskning - kliniske forsøk med bruk av kontrollgrupper - gjorde også den originale Helsinkideklarasjonen mindre relevant for forskernes hverdag da den etter hvert ble mer kjent (14-16, 22, 24). Enger anså det ubetingede kravet til samtykke i den opprinnelige deklarasjonen som problematisk. Han mente, i likhet med flere andre, at det i visse tilfeller måtte kunne utvises skjønn rundt dette $(16,19,25)$.

Helsinkideklarasjonen ble betydelig utvidet og omarbeidet med revisjonen i 1975 (6). I den nye versjonen erstattet man begrepet «klinisk forskning» med «biomedisinsk forskning», for å omfatte andre typer forskning på mennesker eller humant materiale. Det ble åpnet for forskning på etiologi og patogenese i tillegg til kun terapi. Den nye deklarasjonen nevnte også bruk av kontrollgrupper eksplisitt. Tidsskrifter ble frarådet å publisere resultater som hadde fremkommet av forskning der prinsippene i deklarasjonen ikke var fulgt.

Den største og mest påfallende endringen i Helsinkideklarasjonen av 1975 var del I, punkt 2 og punkt $12(6,23,26)$. Disse punktene beskrev tydelig at forsøkene skulle være klart beskrevet i en forsøksprotokoll som skulle fremlegges en «spesielt opp- nevnt uavhengig komité til gjennomgåelse, uttalelse og veiledning». Protokollen skulle inneholde en drøfting av etiske omstendigheter og en bekreftelse på at prinsippene i deklarasjonen var overholdt.

Revisjonen åpnet for å unnlate å innhente samtykke dersom informasjon om forsøket ville påvirke pasientens situasjon negativt. Dette skulle imidlertid være grundig diskutert og begrunnet i forsøksprotokollen, som så altså måtte godkjennes av en etisk komité. Kravet om informert samtykke ble altså mindre og mindre absolutt - fra Nürnberg-kodeksens utvetydige påbud via Helsinkideklarasjonens mulighet til å bruke verges samtykke til den nå reviderte deklarasjonens åpning for å unnlate å innhente samtykke overhodet, med god begrunnelse og godkjenning fra uavhengig komité.

Parallelt med at kravet om samtykke fikk en stadig mindre fremtredende plass i forskningsetiske retningslinjer, vokste det nye kravet om forskningsetiske komiteer frem. Det måtte åpnes for mer skjønn i de etiske vurderingene, men man ønsket ikke å bruke forskerens eget etiske skjønn.

Det sto ingenting i den reviderte Helsinkideklarasjonen om hvordan komiteene skulle organiseres eller hvem som skulle sitte i dem. Ifølge Erik Enger (23) var det enighet på samlingen der revisjonen ble vedtatt om at World Medical Association anbefalte opprettelsen av slike komiteer, men at detaljene rundt organiseringen skulle være opp til det enkelte land. Han kommenterte også at revisjonen «innebærer at tiden nå er inne også i vårt land til å diskutere spørsmålet om å opprette slike komiteer og spørsmålet om deres funksjon» (23). Den norske legeforening ga deklarasjonen sin tilslutning (23), og den ble stående med kun mindre endringer frem til en ny omfattende revisjon ble gjort i 2000 (6).

Gro-saken - Tortur i norsk vitenskap Fra slutten av 1960-årene og utover i 70årene ble allmennheten mer skeptisk til «ekspertveldet», og man stolte ikke lenger blindt på at fagfolk, for eksempel leger og forskere, hadde et pålitelig moralsk kompass $(27,28)$. Mediene fikk en mer aktiv rolle i debatten rundt forskning og behandling, og leger ble oppfordret til å være mer bevisst på hvordan de skulle opptre for å unngå «sensasjonspregete opplysninger til pressen» (29).

Vinteren 1974 satte Dagbladet søkelys på «vitenskapens plass i samfunnet vi lever i» 
(30) (fig 1). Som et ledd i denne debatten kjørte avisen, med journalistene Arne Skouen og Gerd Benneche i spissen, en målrettet kampanje mot uetisk forskning. 19. februar kom den første avsløringen i det som senere skulle få navnet Gro-saken: Skouens artikkel Tortur $i$ norsk vitenskap (31). I artikkelen refererte Skouen fra en forskningsrapport fra Nordisk psykologi (32), der «Gro» ble presentert.

Gro hadde bodd på institusjon fra hun var fem år (fig 2) (33). Ved innleggelsen hadde hun fătt diagnosen «oligofrenia, retardatio mentalis», som Skouen oversatte med «intelligensdefekt med tilhørende mental tilbakeståenhet». Forskerne, Arne Brekstad og Willy-Tore Mørch, møtte Gro da hun var 11 år gammel. Da hadde hun vært fastspent med lærreim i to år, hele døgnet, unntatt i stellesituasjoner.

I artikkelen beskrev Skouen hvordan forskerne brukte 11-åringens situasjon som utgangspunkt for å prøve ut atferdsterapi med belønning hvis hun oppførte seg som de ville og med straff hvis hun ikke gjorde det. Han avsluttet med å fortelle at Dagbladet hadde sendt brev til Sivilombudsmannen med oppfordring om «(å) gjøre affæren Gro gjenstand for etterforskning».

I artikkelen argumenterte Skouen hardt mot forskernes innstilling og manglende refleksjon rundt Gros situasjon. Forskningsartikkelen inneholdt ingen etisk eller juridisk diskusjon om hvorvidt de hadde innhentet samtykke - fra Gro eller hennes foresatte - eller hvorvidt forskernes metoder for øvig kunne forsvares etisk: «Vitenskapelig filosofi og ansvar er ikke deres bord.» $\mathrm{Og}$ videre: «Når de beskriver den ni måneder lange torturperioden, forlater de oss som sosiale individer.»

Skouens artikkel ble utgangspunkt for stor debatt i Dagbladet de påfølgende dagene. Eksperter fra forskjellige fagfelter uttalte seg om saken, deriblant advokater, pedagoger, psykiatere og politikere. Saken ble også debattert i NRKs Kveldsforum.

Få dager etter den første avsløringen startet Helsedirektoratet en utredning av saken (34-38).

Willy-Tore Mørch fikk også anledning til å svare på anklagene (39). Han var student ved Psykologisk institutt ved Universitetet i Oslo mens han var medansvarlig for forskningsprosjektet, men presiserte at instituttet ikke hadde vært informert om prosjektet. Det faktum at navnet på instituttet sto under forfatternes navn i forskningsrapporten, var kun en formalitet fordi Brekstad jobbet der, ifølge Mørch.

I samme avis sto et leserinnlegg fra instituttbestyrer Leif J. Braaten ved Psykologisk institutt (40). Han presiserte at vanlig praksis ved instituttet var at «vitenskapelige undersøkelser tilrettelegges og faglig forestås av en eller flere personer blant vårt vitenskapelige personale, uten at instituttets sentrale organer (styre og råd) i regelen involveres. I hovedsak er det således den enkelte forsker som står faglig-etisk ansvarlig for sitt arbeid. Det instituttet tar ansvar for er at den enkelte forsker blir ansatt ut fra en vurdering av hans vitenskapelige og pedagogiske kvalifikasjoner».

Skal man følge disse resonnementene, var det altså fullt mulig for en forsker å foreta seg omtrent det han ville så lenge det kunne forsvares faglig, uten at institusjonen han var tilknyttet skulle holdes ansvarlig. Institusjonen på sin side kunne hevde at man ikke hadde kjennskap til prosjekter som ble gjennomført av deres ansatte. Institusjonens ledelse hadde gjort sin jobb med å sikre etisk forsvarlighet idet den ansatte forskere som den mente holdt mål faglig og pedagogisk. Resten var opp til forskeren selv.

\section{Gro-sakens etterdønninger}

Gro-saken ga grunnlag for bredere diskusjon rundt organiseringen av forskningen i Norge. Gerd Benneche utga i 1977 en bok med utgangspunkt i saken (41). Hun belyste mangelen på ansvarliggjøring som kom til uttrykk gjennom Gro-saken, der en student under veiledning av en ansatt kunne drive et forskningsopplegg uten instituttets kjennskap. Det ble dermed vanskelig å avgjøre hvem som var ansvarlig for at de etiske aspektene ved arbeidet var tilstrekkelig ivaretatt.

Psykologisk institutt opprettet fagetiske retningslinjer og et fagetisk utvalg i 1975 $(42,43)$. Forskning ved instituttet skulle foranlediges av etiske diskusjoner i fagmiljøet og om nødvendig bredere. Benneche omtalte dette i sin bok (41), og mente det delvis skjedde på grunn av Gro-saken. Hun stilte imidlertid spørsmål ved hvorvidt denne organiseringen var god nok, og viste til den reviderte Helsinkideklarasjonen og Erik Engers oppfordring i Tidsskriftet om å danne forskningsetiske komiteer også i Norge (23).

Videre opprettet Rektormøtet for norske universiteter (senere Universitetsrådet) i 1977 en komité til drøfting av fagetiske retningslinjer og fagetiske råd (den såkalte Andenæs-komiteen) (15). Rådet for samfunnsvitenskapelig forskning i Norges almenvitenskapelige forskningsråd (NAVF) fulgte i 1979 opp med en utredning om forskningsetikk og personopplysninger (44). Gro-saken var medvirkende årsak til begge tiltak $(15,44)$.

Andenæs-komiteen anbefalte i sin innstilling opprettelsen av fagetiske råd som skulle hjelpe forskerne å avgjøre etiske tvilstilfel- ler (45). Rådene skulle forankres i forskningsinstitusjonen, det vil i hovedsak si universitetene. Anbefalingen var at de fagetiske rådene kun skulle vurdere tvilstilfeller der forskerne syntes de trengte hjelp til å avgjøre hvorvidt prosjektet innfridde krav til etisk forsvarlighet, og at rådene kunne undersøke planlagte og igangværende forskningsprosjekter på eget initiativ. Komiteen foreslo imidlertid ikke at alle prosjekter skulle forelegges rådene før de iverksattes, som jo var kravet fra Helsinkideklarasjonen. Universitetsrådet sluttet seg til innstillingen i mai 1979 (46), og ba samme år Kirke- og undervisningsdepartementet om å vedta forslaget som forskrift (15).

Andenæs-komiteens anbefalinger og utredningen om forskningsetikk og personopplysninger ble, sammen med flere andre initiativer, viktige grunnlag for at de regionale forskningsetiske komiteene ble opprettet og fikk den formen de har. Utredningene ble sitert og diskutert $i$ en rapport fra en underkomité under Hovedkomiteen for norsk forskning i 1981 (15). Rapporten anses å ha vært viktig for å fremskynde opprettelsen av forskningsetiske komiteer etter en tid med lite aktivitet (5). Den skisserte flere tiltak som var blitt igangsatt, men ikke fulgt opp. Helsinkideklarasjonens krav om etiske komiteer ble grundig diskutert. Rapporten beskrev hva man hittil hadde gjort for å møte dette kravet, og hvordan man burde gå videre.

Gro-saken ble nevnt spesifikt $i$ et resonnement om at fagspesifikke forskningsetiske utvalg ikke var tilstrekkelig, men at man i tillegg trengte et tverrfaglig, koordinerende råd for å unngå kollegialitetsproblemer. Gro-saken var altså til stede i argumentasjonen for forskningsetiske komiteer fra flere hold, også år etter avsløringene i Dagbladet.

\section{Vann på mølla}

Varslere som Beecher og Pappworth har tradisjonelt fătt mye av æren for å ha beredt grunnen internasjonalt for opprettelsen av etiske komiteer $(12,47)$. Man kan imidlertid diskutere hvor stor rolle enkeltpersoner og enkelthendelser egentlig har spilt. En konkurrerende oppfatning er at enkelthendelsene kun er synlige uttrykk for langt mer gradvise, byråkratiske prosesser som er resultater av pragmatiske hensyn - og at disse enkelthendelsene fremstår utslagsgivende der utvikling i tidsånd egentlig har gjort samfunnet mottagelig for slike endringer (14). Når det gjelder Gro-saken, kan man argumentere for at begge deler stemmer.

Den reviderte Helsinkideklarasjonen lå hele tiden som et bakteppe i diskusjonen om forskningsetiske komiteer, som en påmin- 
nelse om at Norge via Legeforeningen hadde forpliktet seg til å opprette disse, men den var altså ikke nok til at man startet prosessen. Norge hang etter andre land på dette området, og man nøyde seg lenge med ad hoc-komiteer og ellers å plassere det etiske ansvaret på den enkelte forsker. Den lukkede faglige diskusjonen rundt Helsinkideklarasjonens krav til forskningsetiske komiteer fikk imidlertid vann på mølla av en skarp offentlig debatt omkring forskningens moralske status, som var blitt muliggjort av samtidens generelle skepsis til autoriteter og det etablerte. To diskusjoner, en faglig og en offentlig, smeltet sammen til et felles krav om tydeligere etisk regulering av forskning.

\section{Nadia Shad Paulsen (f. 1987)}

er medisinstudent.

Forfatter har fylt ut ICMJE-skjemaet og oppgir ingen interessekonflikter.

\section{Anne Kveim Lie (f. 1969)}

er lege og førsteamanuensis i medisinsk historie.

Forfatter har fylt ut ICMJE-skjemaet og oppgir ingen interessekonflikter.

\section{Litteratur}

1. Lover REK. https://helseforskning.etikkom.no/ ikbViewer/page/reglerogrutiner/loverogregler? p dim=34770\& ikbLanguage Code $=n(14.5 .2016)$

2. REK. Annet vurderingsgrunnlag. https://helseforskning.etikkom.no/ikbViewer/ page/reglerogrutiner/loverogregler/ annetgrunnlag?p_dim $=34771 \&$ \&ikbLanguage Code=n (14.5.2016).

3. Helseforskning REK. https://helseforskning etikkom.no/ikbViewer/page/reglerogrutiner/ soknadsplikt?p_dim=34997\&_ikbLanguage Code $=n$ (14.5.2016)

4. Ruyter KW. Førde R, Solbakk JH. Medisinsk og helsefaglig forskningsetikk. I: Ruyter KW, Førde R, Solbakk JH, red. Medisinsk og helsefaglig etikk. Oslo: Gyldendal Akademisk, 2007: 182-237.

5. Lahlum E Ruyter KW. Opprettelsen av etiske komiteer for medisinsk forskning. Tidsskr Nor Legeforen 2012; 132: 1486-9.

6. Carlson RV, Boyd KM, Webb DJ. The revision of the Declaration of Helsinki: past, present and future. Br J Clin Pharmacol 2004; 57: 695-713.
7. Weindling P. «No Mere Murder Trial»: The Discourse on Human Experiments at the Nuremberg Medical Trial. I: Roelcke V, Maio G, red. Twentieth Century Ethics of Human Subjects Research: Historical Perspectives on Values, Practices, and Regulations. Stuttgart: Franz Steiner Verlag, 2004 167-80.

8. Lederer SE. Research Without Borders: The Origins of the Declaration of Helsinki. I: Roelcke V, Maio G, red. Twentieth Century Ethics of Human Subjects Research: Historical Perspectives on Values, Practices, and Regulations. Stuttgart. Franz Steiner Verlag, 2004: 199-217.

9. Rickham PP. Human Experimentation. Code of Ethics of the World Medical Association. Declaration of Helsinki. BMJ 1964: 2: 177.

10. Beecher HK. Ethics and clinical research. N Engl J Med 1966; 274: 1354-60

11. Pappworth MH. Human Guinea Pigs: Experimentation on Man. London: Routledge, 1967.

12. Edelson PJ. Henry K. Beecher and Maurice Pappworth: Honor in the Development of the Ethics og Human Experimentation. I: Roelcke V, Maio G, red. Twentieth Century Ethics of Human Subjects Research: Historical Perspectives on Values, Practices, and Regulations. Stuttgart: Franz Steiner Verlag, 2004: 219-33.

13. Hedgecoe A. «A form of practical machinery»: the origins of Research Ethics Committees in the UK 1967-1972. Med Hist 2009: 53: 331-50.

14. Stark LJM. Behind Closed Doors: IRBs and the Making of Ethical Research. Chicago: The University of Chicago Press, 2012.

15. Forskning og etisk ansvar: en rapport fra utvalget for «forskning og etikk» nedsatt av Hovedkomiteen for norsk forskning. Oslo: NAVF, 1981.

16. Enger E. Kontrollerte kliniske forsøk. Oslo: Universitetsforlaget, 1966

17. Broch OJ. Det kunstige menneske. Oslo: Minerva, 1969

18. Hjort PF. Tanker om medisinen i fremtidens samfunn. Tidsskr Nor Lægeforen 1967; 87: 1663-70.

19. Strøm A. Legen, pasienten og samfunnet: problemer i legeetikk. Oslo: Fabritius, 1976

20. Greene JA, Jones DS, Podolsky SH. Therapeutic evolution and the challenge of rational medicine. N Engl J Med 2012; 367: 1077-82.

21. Podolsky SH. The Antibiotic Era : Reform, Resistance, and the Pursuit of a Rational Therapeutics. Baltimore: Johns Hopkins University Press, 2015.

22. Riis P. Helsinki Deklarationen: historien bag 2. udgave fra 1975. Bibl Læger 2002; 194: 113-8.

23. Enger E. Helsinki-deklarasjonen - revidert forskningsetikk. Tidsskr Nor Lægeforen 1976: 96 : 467-71.

24. Riis P. Forty Years of the Declaration of Helsinki: Progress in Medical Ethics? I: Schmidt U, Frewer A, red. History and Theory of Human Experimentation: The Declaration of Helsinki and Modern Medical Ethics. Stuttgart: Franz Steiner Verlag. 2007: 165-71.

25. Hill AB. Medical ethics and controlled trials. BMJ 1963; 1: 1043-9.
26. Carlson R, Boyd K, Webb D. The Interpretation of Codes of Medical Ethics. I: Schmidt U, Frewer A red. History and Theory of Human Experimentation: The Declaration of Helsinki and Modern Medical Ethics. Stuttgart: Franz Steiner Verlag, 2007: 187-202

27. Sundström JC, Solheim J. Den allmektige legen: lege og pasient i dagens samfunn: en debattbok. Oslo: Aschehoug, 1970.

28. Sejersted F. Sosialdemokratiets tidsalder: Norge og Sverige i det 20. århundre. Oslo: Pax Forlag. 2013

29. Rådet for legeetikk. Artikler i pressen om kirurgiske inngrep. Tidsskr Nor Lægeforen 1968; 80 1987

30. Skouen A. Torturmetoder i norsk vitenskap. Dagbladet 19.2.1974: 1

31. Skouen A. Tortur i norsk vitenskap. Dagbladet 19.2.1974: 17

32. Brekstad A, Mørch W-T. Et atferdsteoretisk behandlingsopplegg for en 12 år gammel pike med sterkt avvikende sosial atferd. Nord Psykol 1973; 25: 308- 15.

33. Omsorg i endring. Klæbu: Klæbu historielag, 2014.

34. Benneche $G$. Luk vekk de fine ordene - dette er hard straff! Dagbladet 20.2.1974: 12

35. Tilfellet Gro ryster Stortinget: Sivilombudsmannen - en passiv vokter. Dagbladet 22.2.1974: 1.

36. Hamnefjell E. Sterke reaksjoner blant stortingsrepresentantene. Dagbladet 22.2.1974: 14.

37. Ingen fagfolk kan stå utenfor loven. Dagbladet 22.2.1974: 14

38. Helsedirektoratet har påbegynt undersøkelse. Dagbladet 26.2.1974: siste side.

39. Stenstrøm 0. Flere barn lenkes fast til veggene. Dagbladet 20.2.1974: 12

40. Braaten LJ. Psykologisk institutt: Presse-etisk betenkelig. Dagbladet 20.2.1974: siste side.

41. Benneche G. I det andre huset: en beretning om myndige og umyndige i vårt omsorgs-samfunn. Oslo: Gyldendal, 1977

42. Reglement for fagetisk utvalg ved Psykologisk institutt. Oslo: Psykologisk institutt, 1975.

43. Fagetiske retningslinjer for Psykologisk institutt. Oslo: Psykologisk institutt, 1975.

44. Forskningsetikk og personopplysninger: utredning. Oslo: NAVF, 1979.

45. Andenæs-komiteens utkast til forskrifter om råd for forskningsetikk ved universitet og høyskole. I: Forskningsetikk og personopplysninger: utredning. Oslo: NAVF, 1979.

46. Protokoll fra det 4. møte i Det norske universitetsråd 28. og 29. mai 1979. Oslo: Det norske universitetsråd, 1979

47. Rothman DJ. Strangers at the bedside: a history of how law and bioethics transformed medical decision making. New York: BasicBooks, 1991.

Mottatt 30.7. 2016, første revisjon innsendt 22.9. 2016, godkjent 23.9. 2016. Redaktør: Ketil Slagstad. 